Niepełnosprawność. Dyskursy pedagogiki specjalnej

Nr 31/2018

Disability. Discourses of special education

No. 31/2018

Edyta Nieduziak

Uniwersytet Śląski w Katowicach

\title{
Realizacja zadań otoczenia społecznego we wspieraniu możliwości edukacyjnych i tworzeniu perspektyw wobec osób we złożoną niepełnosprawnością na przykładzie biograficznego studium przypadku
}

Artykuł ma na celu zaprezentowanie działań otoczenia społecznego, podejmowanych wobec 25-letniej dziewczyny ze złożoną niepełnosprawnością, wychowującą się w szczególnych warunkach - oboje rodzice są osobami ze zdiagnozowaną chorobą psychiczną. Droga rozwojowa dziewczyny przebiegała równolegle do powstających w miejscu zamieszkania instytucji edukacyjnych i terapeutycznych dla dzieci z niepełnosprawnością oraz form pomocy dla dorosłych niepełnosprawnych. Możemy więc prześledzić uczestnictwo dziecka w różnych formach edukacji i wsparcia oraz śledzić formy pomocy oferowane rodzinie. Biografia jest przykładem dla pokazania zadań, jakie ma do spełnienia otoczenie społeczne wobec osób z niepełnosprawnością i ich najbliższych, oraz tego, jak z tych zadań się wywiązuje.

Słowa kluczowe: niepełnosprawność intelektualna, autyzm, otoczenie społeczne, edukacja specjalna, rehabilitacja społeczna, środowiskowy dom samopomocy, wsparcie

\section{Implementation of social environment tasks in supporting educational opportunities and creating perspectives for people with complex disabilities on the example of a biographical case study}

The article aims to present the activities of the social environment, taken against 25-year-old girl with complex disability, growing up in particularly conditions - both parents are people diagnosed with mental illness. The developmental path of the girl ran parallel to the educational and therapeutic institutions emerging at the place of residence for children with disabilities and forms of assistance for adults with disabilities. We can trace the child's participation in various forms of education and support and follow the forms of help offered to the family. This biography is an example for showing the tasks to be fulfilled by the social environment for people with disabilities and their relatives, and how these tasks are fulfilled.

Keywords: intellectual disability, autism, social environment, special education, social rehabilitation, community self-help house, support 


\section{Wprowadzenie}

W bardzo ogólnym rozumieniu można przyjąć, że istota niepełnosprawności sprowadza się do układu cech biologicznych (w modelu medycznym) i/lub warunków społecznych (model społeczny), które powodują ograniczone możliwości uczestnictwa w całokształcie życia jednostkowego, własnego i grupowego, społecznego. W klasycznym już podejściu wyraża się to w podziale aspektów niepełnosprawności na biologiczny, psychologiczny i społeczny, które wzajemnie siebie warunkują [Kowalik 2007]. Obecnie, zwłaszcza w naukach społecznych, jak też w opracowaniach o charakterze prawnym, szczególny nacisk jest kładziony na społeczne uwarunkowania niepełnosprawności. Przykładem jest chociażby Międzynarodowa Klasyfikacja Funkcjonowania, Niepełnosprawności i Zdrowia ICF (2009: 19), w której „funkcjonowanie jednostki w określonej dziedzinie jest postrzegane jako interakcja lub złożony wzajemny związek między stanem zdrowia a czynnikami kontekstowymi (tzn. czynnikami środowiskowymi i osobowymi)". Tym samym, nie odrzucając biologicznych uwarunkowań stanu choroby i niepełnosprawności, dokument ten wskazuje, jak ważną grupę czynników decydujących o definiowaniu niepełnosprawności stanowi kontekst społeczny. Nie preferując żadnego z modeli niepełnosprawności, podejście zaproponowane w ICF, nie jest kompromisem pomiędzy modelem biologicznym a modelem społecznym niepełnosprawności, lecz próbą integracji rozmaitych wymiarów funkcjonowania osób, wyrażającą się w podejściu „biopsychosocjalnym” [tamże: 20]. Co ważne, podejście to nie zakłada równowagi wpływu czynników biologicznych, osobowych i społecznych, lecz podkreśla ich zróżnicowanie, co ostatecznie wyraża się w indywidualnych losach osób chorych i niepełnosprawnych.

Na naszym rodzimym gruncie dyskusje na temat paradygmatów niepełnosprawności nie są nowością ${ }^{1}$ i często sprowadzają się do krytyki modelu biologicznego, ale też wytykają niedostatki podejścia społecznego [Krause 2010]. Wydaje się, że jak podają E. Wapiennik i R. Piotrowicz [2002: 22-23], droga rozwoju podejść i rozumienia niepełnosprawności wiedzie właśnie do uznania wpływu czynników różnej natury i przyjmowania coraz częściej modelu biopsychospołecznego. Zaletą takiego pojmowania jest odejście "od modelu patogennego na rzecz salutogennego, a tym samym od oglądu człowieka przez wyłączny pryzmat choroby (niepełnosprawności) ku patrzeniu na niego w perspektywie posiadanych zasobów zdrowotnych i biologicznych strategii prewencji" [Wojciechowski, Opozda-

1 Bardzo silnie ten wątek zaznaczył się podczas wystąpień i obrad uczestników XIV Konferencji Naukowej z cyklu Dyskursy Pedagogiki Specjalnej organizowanej przez Zakład Pedagogiki Specjalnej, Instytutu Pedagogiki na Wydziale Nauk Społecznych Uniwersytetu Gdańskiego nt. „Niepełnosprawność wobec zmiany - zmiany wobec niepełnosprawności" w maju 2017 r. 
Suder 2013: 105]. Z. Palak [2004: 106] zauważa, że przyjęcie właśnie biopsychospołecznej koncepcji niepełnosprawności implikuje systemowy model pomocy uwzględniający trzy poziomy funkcjonowania człowieka: biologiczny, jednostkowy i społeczny. Podejście to ma swoje konsekwencje praktyczne i przejawia się $\mathrm{w}$ sposobie działania instytucji pomocowych, edukacyjnych, rehabilitacyjnych, które określa się także jako instytucje wsparcia społecznego.

W cytowanej wyżej Klasyfikacji ICF [2009: 43-44, 187-189] wsparcie jest, obok produktów i technologii, środowiska naturalnego, postaw społecznych oraz usług, systemów i polityki, jednym z czynników środowiskowych warunkujących funkcjonowanie osób chorych i niepełnosprawnych. Wsparcie to tworzą przede wszystkim: rodzina, przyjaciele, znajomi, rówieśnicy, koledzy, sąsiedzi, członkowie lokalnej społeczności, ludzie posiadający władzę, podwładni, opiekunowie i asystenci osobiści, osoby obce, zwierzęta, pracownicy ochrony zdrowia, fachowcy z różnych dziedzin. Można zatem przyjąć, że wsparcie społeczne jest formą pomocy kierowanej do konkretnych osób bądź grup społecznych w sytuacjach dla nich trudnych, stresowych, przełomowych, w których bez tego wsparcia nie byliby w stanie sobie poradzić [Kawula 1997: 15]. Przy czym, jak podaje A. Axer [1983: 200], źródłem wsparcia mogą być osoby z najbliższego otoczenia, również organizacje skupiające profesjonalistów albo powstające spontanicznie oraz programy, instytucje bądź ich sieci, udzielające pomocy.

Ich działania przekładają się na biografie odbiorców wsparcia, z drugiej strony jednakże te indywidualne biografie ukazują ewolucję form wparcia, ich zmiany wynikające z dostosowywania się do potrzeb osób chorych i niepełnosprawnych, jak również ze zmieniającego się środowiska, warunków życia, rozwoju technologii i relacji międzyludzkich. Wsparcie społeczne opiera się przecież na wymianie między biorcą a dawcą wsparcia, zgodnie z potrzebami biorcy i możliwościami wspierającego [Sęk, Cieślak 2004: 18].

\section{Metodologia badania}

Mając na uwadze powyższe założenia przeprowadziłam badania jakościowe studium przypadku, 25-letniej dziewczyny ze złożoną niepełnosprawnością (niepełnosprawność intelektualna i autyzm), absolwentki szkoły specjalnej. Jej biografia zasługuje na szczególną uwagę m.in. ze względu na wychowywanie się w wyjątkowo trudnych warunkach - oboje rodzice są doświadczeni chorobą psychiczną, która ujawniła się jeszcze przed narodzinami dziecka. Złożoność sytuacji życiowej całej rodziny powodowała, że poszczególni członkowie wymagali wsparcia, często też wsparcia specjalistycznego - psychiatrycznego. Interesowały mnie jednak nie tyle losy całej rodziny, lecz indywidualna biografia dziecka, dziś 
osoby dorosłej. Główny problem badawczy sprowadzał się więc do pytania, jak otoczenie społeczne, w którym funkcjonowała i funkcjonuje rodzina, wspierało i wspiera możliwości edukacyjne dziecka oraz pomaga $\mathrm{w}$ planowaniu jego przyszłości?

Tak postawiony problem wymagał przyjęcia paradygmatu interpretatywnego, a w nim podejścia biograficznego, którego przedmiotem jest życie konkretnej osoby. Wybór metodologii wynikał z jej podstawowego założenia, a mianowicie przekonania, że „wszystkie procesy makrostrukturalne - czyli dotyczące dużych zbiorowości ludzkich, takich jak klasy, warstwy, narody czy wyznania - są zakorzenione w poziomie mikro, czyli w życiu konkretnych jednostek, które te zbiorowości współtworzą. Jednocześnie życie pojedynczego człowieka zawiera w sobie - niczym hologram - informację o społeczeństwie i czasach, w których żyje. Badamy biografię nie tylko po to, żeby poznać człowieka [...], lecz także po to, by spojrzeć na cały świat społeczny zapisany w jego losie" [Bednarz-Łuczewska, Łuczewski 2012: 91]. Biografia badanej dziewczyny, choć relatywnie niedługa, okazuje się już wystarczająca by zauważyć zmiany, jakie zaszły w instytucjach wparcia w ostatnim ćwierćwieczu. Tym samym, interesujący okazuje się efekt badań nie tylko w wymiarze jednostkowym, również dlatego, że tłem dla niego stały się ważne zmiany społeczne.

Należy zwrócić jeszcze uwagę, że przedmiotem badań są losy jednej osoby, co sytuuje badania w strategii badawczej studium przypadku. Jej celem jest dokonanie pogłębionej analizy określonego przypadku wraz z kontekstem, w jakim funkcjonuje [Yin 2015]. Zastosowanie tego podejścia wymagało wykorzystania różnorodnych technik zbierania danych, takich jak: wywiady, obserwacja czy analiza dokumentów. Nieograniczanie się w sposobie gromadzenia danych tylko do wywiadu biograficznego wynikało z możliwości komunikacyjnych badanej osoby, uwarunkowanych niepełnosprawnością intelektualną w stopniu umiarkowanym i autyzmem. Powstała więc konieczność uzupełniania ich innymi źródłami. Były to w większości wywiady z nauczycielami ze szkoły specjalnej oraz z matką. Badania były prowadzone w okresie od października 2016 r. do maja $2018 \mathrm{r}$.

\section{Wstępna charakterystyka osoby i środowiska jej życia}

A.K. ${ }^{2}$ ma obecnie 25 lat, pierwszą diagnozę niepełnosprawności otrzymała $\mathrm{w}$ wieku 2 lat, była to diagnoza upośledzenia umysłowego w stopniu umiarkowanym. Pięć lat później, w 7 roku życia dziecka, diagnoza została uzupełniona

2 W celu ochrony danych osobowych inicjały badanej zostały zmienione. Nie podaję też pełnych nazw ośrodków, placówek edukacyjnych i terapeutycznych. 
stwierdzeniem autyzmu. Obecnie dziewczyna legitymuje się orzeczeniem o niepełnosprawności w stopniu znacznym, ze względu na: niepełnosprawność intelektualną (upośledzenie umysłowe - nadal w nomenklaturze medycznej; symbol 01-U) oraz całościowe zaburzenia rozwojowe, powstałe przed 16 rokiem życia, $\mathrm{z}$ utrwalonymi zaburzeniami interakcji społecznych lub komunikacji werbalnej oraz stereotypiami zachowań, zainteresowań i aktywności o co najmniej umiarkowanym stopniu nasilenia (symbol 12-C).

Mieszka w trzypokojowym mieszkaniu z babcią i rodzicami, którzy chorują i leczą się psychiatrycznie. Nie ma rodzeństwa. $Z$ powodu obciążenia rodziców chorobą, osobą podejmującą decyzje w domu jest babcia dziewczyny, która również sprawuje nad nią opiekę $\mathrm{w}$ okresach pogorszenia stanu zdrowia rodziców. Mama dziewczyny uczęszcza do środowiskowego domu samopomocy, który jest placówką znaną córce od dzieciństwa. A. przychodziła tam i uczestniczyła w zajęciach plastycznych w okresach wolnych od zajęć szkolnych, oczekując na wspólny z mamą powrót do domu. Dziewczyna ukończyła wszystkie etapy edukacji specjalnej: od szkoły podstawowej po szkołę przysposabiającą do pracy. Obecnie uczęszcza na zajęcia w środowiskowym domu samopomocy.

Jest osobą o pogodnym usposobieniu, kontaktową i towarzyską, mimo diagnozy ASD. Potrafi utrzymać kontakt wzrokowy z drugą osobą, a w sytuacjach, gdy czuje się bezpiecznie, rozmawia. Jej sposób komunikowania się werbalnego charakteryzuje używanie krótkich zdań, a w nich licznych neologizmów, pojawiają się także echolalie bezpośrednie i odroczone. Specyficzny jest sposób poruszania się - powolny, niezgrabny, posuwisty. Jest nieco przygarbiona. Lubi kiwać się na krześle, nakręcać włosy na palec, głośno wzdychaći charakterystycznie wydymać usta. Zawsze jest starannie ubrana.

\section{Biografia}

Z wywiadu z matką wynika, że A. była dzieckiem chcianym i oczekiwanym. W czasie ciąży matka musiała przyjmować leki i miała jedną hospitalizację na oddziale psychiatrycznym. Dziecko urodziło się zdrowe, w terminie, siłami natury. Jednakże dzieciństwo naznaczone było chorobami oraz problemami w adaptacji. Dziewczynka przejawiała zachowania trudne - rzucała zabawkami, kiwała się, uderzała głową o wersalkę, przyjmowała różne pozycje na podłodze lub uciekała w przestrzeń ograniczoną.

Pierwsze niepokojące objawy dotyczące rozwoju dziecka zostały zauważone przez środowisko medyczne podczas pobytu dwuletniej A. w szpitalu z powodu infekcji układu moczowego. Lekarze zwrócili uwagę na opóźnienie rozwoju dziecka, co w konsekwencji doprowadziło do postawienia diagnozy o upośledzeniu 
umysłowym w stopniu umiarkowanym. Pomimo niepełnosprawności dziecko rozpoczęło edukację przedszkolną w wieku 3 lat w placówce publicznej ogólnodostępnej. Takie rozwiązanie wynikało $\mathrm{z}$ braku, wówczas w miejscu zamieszkania, innych rozwiązań dla dzieci niepełnosprawnych. Dzięki otwartości dyrekcji placówki, dziecko spędzało w przedszkolu trzy godziny dziennie, zawsze $\mathrm{w}$ asyście mamy. Stan taki trwał przez trzy lata, do momentu, kiedy powstało przedszkole integracyjne. Utworzenie placówki specjalistycznej, ale jednocześnie otwartej dla dzieci sprawnych stworzyło możliwość poddania A. oddziaływaniom, prowadzonym przez kadrę specjalistów oraz dalszej stymulacji rozwoju społecznego przez kontakt z dziećmi.

Niestety, utrzymujące się zachowania trudne prowokowały rodziców do poszukiwania pomocy. $\mathrm{W}$ wieku 6 lat, a więc w czasie zmiany przedszkola, dziewczynka została poddana konsultacji specjalistów, w najbliższym oddziale Krajowego Towarzystwa Autyzmu. Wynik konsultacji, z jednej strony mógł wydawać się optymistyczny, bowiem nie stwierdzono u dziecka zachowań ze spektrum autystycznego, z drugiej strony nie dawał jednoznacznej odpowiedzi o źródła niepokojących symptomów. Przyczyn zaburzeń i dysharmonii rozwojowej upatrywano w wysokim poziomie lęku, co odbijało się, zdaniem konsultanta, niekorzystnie na rozwoju intelektualnym. Sugerował nawet, że "możliwości intelektualne są większe niż można sądzić z jej zachowania". Mimo wysiłku pedagogów i samych rodziców oraz dziadków, dziewczynka przejawiała zachowania izolujące m.in. przed hałasem i głośnymi dźwiękami. Problemy pogłębiały zaburzenia rozwoju mowy. W wieku 6 lat dziecko wokalizowało, sylabowo i nuciło melodie, nie posługiwało się jednak mową werbalną. Utrudniało to nawiązywanie relacji interpersonalnych. Jedynie w wyjątkowo sprzyjających sytuacjach, kiedy dziewczynka czuła się pewnie, można było usłyszeć pojedyncze słowa. To utwierdzało w przekonaniu, że przyczyny zaburzeń mają podłoże emocjonalne. Rodzina nie mogła liczyć na specjalistyczne formy wsparcia czy terapii, ponieważ w okolicy takich nie było. Pierwsze proste zdania, dziecko zaczęło wypowiadać w 7 roku życia.

Złożone spektrum zaburzeń było argumentem w staraniach rodziców o odroczenie realizacji obowiązku szkolnego. Tym samym dziewczynka rozpoczęła naukę w szkole podstawowej dopiero mając 9 lat. Orzeczenie o potrzebie kształcenia specjalnego wydane przez poradnię psychologiczno-pedagogiczną uzasadniono diagnozą niepełnosprawności intelektualnej w stopniu umiarkowanym, niepełną diagnozą psychologiczną z podejrzeniem autyzmu i deficytami w sferze społecznej. Dla rodziców, oczywistym było, że dziecko należy posłać do szkoły specjalnej. Przekroczenie progu edukacyjnego, które wymagało zmiany środowiska wychowawczego, okazało się wielkim wyzwaniem dla dziewczynki. Poza naturalnym w takich okolicznościach stresem, dodatkową przeszkodą były nadmiernie 
opiekuńcze postawy rodziców, a zwłaszcza babci. U progu nauki w szkole podstawowej A. nie potrafiła sama ubierać się, myć, czasem nie sygnalizowała potrzeb fizjologicznych, była niesamodzielna $\mathrm{w}$ samoobsłudze, zanieczyszczająca się i nieporadna.

Dziewczynka potrzebowała dużo czasu na identyfikację z grupą klasową oraz zajęcie miejsca w ławce. Nadwrażliwość na bodźce słuchowe, duża ilość dzieci sprawiały, że wycofywała się i ukrywała zwłaszcza podczas przerw międzylekcyjnych. Była bardzo nieufna i lękliwa wobec obcych osób, nie nawiązywała relacji z rówieśnikami. Ale to właśnie w szkole specjalnej, pod wpływem pracy nauczycieli i terapeutów zaczęła podejmować pierwsze próby kontaktu werbalnego. Nie formułowała pytań, a na zadane pytania odpowiadała: „tak” lub „nie”. Utrudnieniem były problemy z emisją głosu wyrażające się w braku kontroli nad jego natężeniem i wysokością dźwięku. To powodowało, że na zajęciach lekcyjnych była cicha, wycofana, nie inicjowała kontaktu ani z rówieśnikami, ani z dorosłymi. Czasami nie odpowiadała na pytania, robiła się spięta, zdenerwowana, głośno oddychała, rozglądała się. Utrzymywały się u niej stereotypie ruchowe.

Uczęszczanie do szkoły specjalnej dało jednak możliwość realizacji zajęć lekcyjnych i terapeutycznych $\mathrm{w}$ formie indywidualnej, co okazało się dobrym rozwiązaniem i impulsem do opanowania zachowań lękowych na rzecz większej otwartości, ufności wobec nauczycieli, a z czasem także ujawniania własnych możliwości i potencjału. Wrażliwość na bodźce słuchowe okazała się związana z nieprzeciętnymi zdolnościami muzycznymi, co potwierdziły opinie konsultantów specjalistów. W drugiej klasie specjalnej szkoły podstawowej dziewczynka rozpoczęła dodatkowe zajęcia z muzyki, muzykoterapii oraz zaczęła uczęszczać do kółka muzycznego. Chętnie śpiewała, powtarzała dźwięki w różnych tonacjach pamiętała je i z zainteresowaniem chciała grać na instrumentach. Mimo braku umiejętności czytania z nut, nauczyła się grać na keyboardzie. W czasie zajęć muzykoterapeutycznych spontanicznie reagowała na dźwięki, wyrażając gestami, mimiką, słowami czy ruchem swój nastrój. Znikało napięcie mięśniowe, poddawała się muzyce, która wyraźnie ją uspokajała i relaksowała.

W szkole specjalnej zauważono również dobrą sprawność manualną dziewczynki oraz rozbudzono zainteresowanie plastyką, a w szczególności spontanicznym rysunkiem. A. chętnie współpracowała, wytrwale kończąc powierzone zadania. Wykonywane prace charakteryzowała staranność, dokładność i wielobarwność. Obserwowało się wówczas dużą potrzebę i radość rysowania pomimo ich wąskiej tematyki i pewnego schematyzmu.

W kolejnych latach edukacji ujawniło się jeszcze jedno zamiłowanie dziewczynki. Był nim język angielski. A. bardzo chętnie uczyła się słówek, zapamiętywała je, a potem często wplatała w swoje wypowiedzi, czasem jako echolalie, cza- 
sem nadając znaczenie wypowiedzi. Lubiła np. witać i żegnać się po angielsku, puentować skończone zadanie słowem „complete”.

Kończąc II etap edukacyjny dziewczynka potrafiła czytać proste teksty, pisać, również ze słuchu, a jej pismo było bardzo staranne. Utożsamiła się z grupą klasową, nawiązała pozytywne relacje, wdrożyła się do panujących w szkole i klasie zasad oraz norm, przyswoiła wiedzę z wynikiem dobrym. W czasie wakacji przychodziła do Środowiskowego Domu Samopomocy, której uczestniczką do dzisiaj jest jej mama. Wówczas spędzała czas w pracowni plastycznej, gdzie swoją spontaniczną twórczością zwróciła uwagę instruktorki-terapeutki: „Chętnie wtedy rysowała sama, bez gotowych wzorów, kolorowanek, podejmując zaproponowane przeze mnie tematy, lub znacznie bardziej - wymyślając swoje obrazy, zwykle figuratywne, przedstawiające jakieś postacie. Rysowała z użyciem dużej siły, wyciskając z kredek maksimum koloru. Każdy rysunek był dla niej ważny i zabierała go ze sobą do domu. Pochłaniało jej to dużo czasu i uwagi. Niewiele wtedy mówiła. I nawet w sytuacji, kiedy mama wychodziła na inne zajęcia, wyjaśniając jej uprzednio gdzie idzie i kiedy wróci, spoglądała tylko na nią i dalej zatapiała się w rysowanie". Do dzisiaj twórczość plastyczna pozostaje jedną z największych pasji dziewczyny.

III etap edukacyjny A. kontynuowała w szkole specjalnej. Rodzice wystąpili o ponowne orzeczenie o potrzebie kształcenia specjalnego na nowy etap edukacyjny. Uzasadniono je upośledzeniem umysłowym w stopniu umiarkowanym oraz autyzmem wczesnodziecięcym (sic!). W załączonej diagnozie psychologiczno-pedagogiczno-logopedycznej znalazły się informacje o ubogim zasobie słownictwa dziewczynki, dalszych problemach z emisją głosu, aczkolwiek prawidłową artykulacją głosek. Odznaczała się niskim poziomem logicznego wnioskowania, miała duże trudności z ujmowaniem zależności przyczynowo-skutkowych oraz przeprowadzeniem prostych operacji myślowych w oparciu o materiał liczbowy. Zespół nisko ocenił umiejętności w zakresie obowiązujących norm i zasad społecznych oraz wiedzy ogólnej. Spośród mocnych stron wyróżniono dobrze funkcjonującą percepcje wzrokową, zdolności plastyczne, staranne pismo oraz zainteresowania muzyczne.

Od 2013 r. dziewczyna posiadała także orzeczenie o stopniu niepełnosprawności, które zostało przedłużone w 2015 r. i, zgodnie z którym posiada znaczny stopień niepełnosprawności. Wśród wskazań wymieniono kontynuację kształcenia specjalnego oraz wymóg „korzystania z systemu środowiskowego wsparcia w samodzielnej egzystencji [...], świadczonych przez sieć instytucji pomocy społecznej, organizacje pozarządowe oraz inne placówki, a także konieczność stałej lub długotrwałej opieki lub pomocy innej osoby w związku ze znacznie ograniczoną możliwością samodzielnej egzystencji”. 
Doświadczenie kontaktu rodziny z gronem nauczycieli szkoły specjalnej zaowocowało mniejszym nasileniem postaw nadopiekuńczych, nadal jednak utrzymywały się trudności z samodzielnym ubraniem, zadbaniem o adekwatny do pogody strój, samodzielnością w utrzymaniu higieny, z przygotowaniem najprostszego posiłku. Nauczyciele gimnazjum specjalnego skupili się $\mathrm{w}$ pracy przede wszystkim na rozwoju zdolności muzycznych dziewczyny i umiejętności gry na instrumencie. Rodzice zakupili córce keyboard, aby mogła ćwiczyć, pracując $\mathrm{w}$ domu. A. zaczęła komponować, w czasie gry używać obu dłoni i niemal wszystkich palców. Zdaniem nauczyciela muzyki miała świetną pamięć do nut, które słyszała, niezwykłą łatwość składania dźwięków w harmonijną melodię oraz potrafiła zagrać każdy zaintonowany przez niego dźwięk. Nadal problem sprawiało jej czytanie partytur, dużo łatwiej grała ze słuchu. Nauczyciel wykorzystał to planując pracę terapeutyczną nad pokonywaniem zachowań lękowych i nabywaniem większej pewności siebie $w$ sytuacjach społecznych. A. reprezentowała szkołę w licznych przeglądach i konkursach muzycznych. Brała udział w występach okolicznościowych organizowanych w szkole. Osoby z najbliższego otoczenia zaczęły doceniać zdolności dziewczyny a najbliższą rodzinę przepełniało poczucie dumy. Zauważalne stały się efekty w sferze rozwoju społecznego i emocjonalnego. Dziewczynka stawała się coraz bardziej ufna, otwarta na innych, lepiej układały się jej relacje z rówieśnikami, również w sferze kontaktów werbalnych. Chętniej zabierała głos, włączała się do rozmów, zadawała pytania. Stała się pogodniejsza, zaczęło znikać nadmierne napięcie mięśniowe, a stereotypie ulegały wytłumieniu. Zaczęła również recytować wiersze. Okazało się, że posiada łatwość w zapamiętywaniu tekstów, praca nad ich wygłoszeniem działała jak terapia logopedyczna utrwalając prawidłową wymogę głosek i korektę zaburzeń emisji głosu. Uczennica z sukcesem reprezentowała szkołę na zewnątrz, w mieście i na etapach wojewódzkich zdobywając pochwały, wyróżnienia i nagrody.

Po ukończeniu gimnazjum A. kontynuowała naukę w szkole przysposabiającej do pracy. Jej rozwój społeczny uwarunkowany był kontynuacją znajomości z wcześniejszego etapu edukacji. Pozostanie $\mathrm{w}$ dotychczasowym środowisku pozwoliło angażować się $\mathrm{w}$ relacje interpersonalne, dziewczyna odważniej nawiązywała kontakty, stosowała formy grzecznościowe, potrafiła podtrzymać rozmowę. Zachowania trudne ulegały wycofaniu. W realizacji zadań szkolnych wykazywała się dużą motywacją, wytrwałością i współpracą. Nadal problem sprawiała samodzielność $\mathrm{w}$ czynnościach codziennych: przygotowywaniu posiłków, utrzymaniu porządku, praniu, prasowaniu, robieniu zakupów (do dziś ma trudności z rozpoznawaniem wartości pieniądza i cen produktów), poruszaniu się w miejscu zamieszkania. Jest to konsekwencja wyręczania z obowiązków w środowisku rodzinnym. 
W czasie ostatniego etapu edukacji zauważalny stał się regres niektórych umiejętności. Dziewczyna miała tendencje do zapominania, „zawieszania się" na danej rzeczy, potrzebowała polecenia, aby czynność zakończyć i przejść do następnej. W okresach lepszego funkcjonowania potrafiła opowiadać o wykonywanych czynnościach, zrelacjonować, czego nauczyła się na lekcji. W dniach gorszego samopoczucia jej deficyty intelektualne były bardziej widoczne, np. myliła nazwy zwierząt $\mathrm{z}$ nazwami drzew, powracały trudności $\mathrm{w}$ relacjach interpersonalnych, np. traciła umiejętność odmawiania w sytuacjach zagrożenia. W szkole kontynuowano muzykoterapię, rozwijano jej umiejętności plastyczne. Brała udział w uroczystościach i występowała przed szerszą publicznością. Mimo widocznego przed prezentacją zdenerwowania, negatywne emocje ustępowały radości w trakcie występu.

$\mathrm{W}$ ramach przygotowania do pracy poza środowiskiem szkolnym, w ciągu ostatnich dwóch lat nauki, dziewczyna uczestniczyła w projektach skierowanych do młodzieży z zaburzeniami autystycznymi i niepełnosprawnością intelektualną, które miały na celu aktywizację intelektualną, ćwiczenia wybranych umiejętności psychologicznych oraz doświadczenia terapii zajęciowej. Przez cały okres edukacji A. była pod opieką psychiatry.

\section{Analiza i dyskusja}

Analiza materiału biograficznego prowokuje do refleksji dotyczących realizacji zadań otoczenia społecznego wobec osób z niepełnosprawnością i ich rodzin. Należy zwrócić uwagę, jak bardzo uzyskanie pomocy i wsparcia uzależnione jest od decyzji formalnych. One z kolei wyznaczają kolejne etapy życia wybranej do badań osoby. Zamieszczony poniżej schemat 1 jest próbą ich zobrazowania wraz z przytoczeniem uzyskanego wsparcia oraz możliwych rozwiązań alternatywnych, które jednak nie zostały zastosowane.

Z wywiadu z matką dziewczyny wiemy, że wiadomość o zaburzeniu rozwojowym dziecka była dla niej bardzo bolesnym i zaskakującym doświadczeniem. Przez lekarza prowadzącego ciążę zapewniana była, że jej choroba, ani choroba męża nie spowodują powikłań rozwojowych u dziecka. Tymczasem stało się inaczej. Choć z punktu widzenia medycznego, rzeczywiście choroba psychiczna rodziców nie ma nic wspólnego z niepełnosprawnością intelektualną dziecka. Pierwszymi osobami, które zwróciły uwagę na zaburzenia rozwojowe byli lekarze. $Z$ jednej strony wydaje się to naturalne i uzasadnione, $z$ drugiej wygląda na to, że ich rola ograniczyła się do standardowego poradnictwa i postawienia diagnozy. Daleko posunięta specjalizacja wśród klinicystów powoduje, że środowisko me- 
dyczne wciąż jeszcze dalekie jest od traktowania pacjentów w sposób holistyczny. Wybrana do badania osoba nie doświadczyła także możliwości wczesnego wspomagania aczkolwiek jak zauważa A. Twardowski (2016) „do połowy lat dziewięćdziesiątych ubiegłego wieku w programach wczesnego wspomagania rozwoju dzieci z niepełnosprawnościami dominował paradygmat medyczny. [...] [którego EN] skuteczność [...] jest niska, pomimo znacznego zaangażowania specjalistów"(s.200-201). Niewykorzystanie tej szansy wynikało z braku w najbliższej okolicy placówki, która świadczyłaby takie usługi. Dziś nie tylko łatwiej o znalezienie takiego miejsca, inaczej też przebiega rehabilitacja, w której większą rolę odgrywają sami rodzice, upełnomocnieni do pełnienia funkcji rehabilitanta i terapeuty własnego dziecka [Tarnowski 2016].

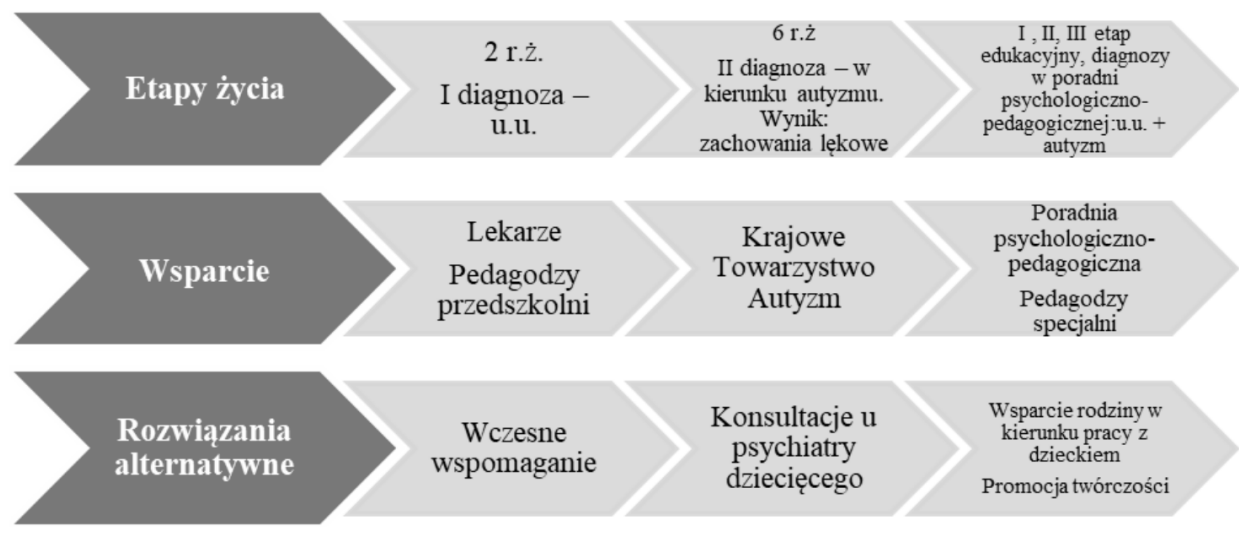

Schemat 1. Etapy życia wybranej do badań osoby

Źródło: Opracowanie własne.

Znacznie większą otwartość na problemy niepełnosprawności wykazało grono pedagogów - nie tylko specjalnych. Zgoda na przebywanie wśród sprawnych rówieśników, dziecka o widocznych problemach z adaptacją do środowiska przedszkolnego, pod koniec lat 90. w Polsce, było bardziej wyrazem odwagi niż realizacją idei integracji czy inkluzji edukacyjnej. Niemniej jednak A. doświadczyła działań integracyjnych na poziomie przedszkolnym. W badanej biografii zauważyć można swego rodzaju ambiwalencję postaw między uczestnictwem $\mathrm{w}$ formach edukacji ogólnodostępnych a specjalistycznych. Wynika ona jednak nie $\mathrm{z}$ wyboru między różnymi formami edukacji, bowiem takiego w gruncie rzeczy nie było, lecz z uznania korzyści z uczestnictwa dziecka w edukacji instytucjonalnej (przedszkole) nad pozostanie w środowisku izolującym (dom). W momencie bowiem rozpoczęcia obowiązkowej edukacji szkolnej wybór placówki specjalistycznej tj. szkoły specjalnej był jednoznaczny, podyktowany specyfiką zaburzeń dziecka. 
I tu natrafiamy na kolejne zagadnienie, dotyczące problemów diagnostycznych. Sugerowana diagnoza autyzmu wczesnodziecięcego budzi wątpliwości. W 6 r.ż. dziecka, rodzice otrzymali opinię, wydaną przez zespół specjalistów Krajowego Towarzystwa Autyzmu, wykluczającą to zaburzenie i sugerującą zaburzenia o podłożu emocjonalnym. Tymczasem orzeczenie o potrzebie kształcenie specjalnego wydane przez zespół orzekający poradni psychologicznopedagogicznej, uzasadnione było niepełnosprawnością sprzężoną (upośledzenie umysłowe i autyzm wczesnodziecięcy). Nasuwają się do przemyślenia dwie kwestie: jedna związana z pytaniem o możliwość bardziej szczegółowej diagnozy psychiatrycznej, którą uzasadniałyby zachowania niemieszczące się w kryteriach autyzmu (tym bardziej wczesnodziecięcego, diagnozowanego do 3 roku życia) oraz specyficzne środowisko wychowawcze dziecka związane z chorobą rodziców; druga kwestia dotyczy konsekwencji w otrzymaniu pomocy społecznej i dotacji dla szkoły, zależnie od rodzaju niepełnosprawności dziecka-ucznia. Konsekwencją eliminacji swego rodzaju zaniedbania w pierwszej kwestii mogłoby być uzupełnienie procesu rehabilitacji i terapii specjalistycznymi oddziaływaniami, których A. nie doświadczyła w szkole. Mogłyby to być oddziaływania o charakterze psychoterapeutycznym, obejmujące całe środowisko rodzinne, co wspomogłoby proces usamodzielniania w codziennych czynnościach, wyraźnie hamowany przez postawy nadopiekuńcze seniorki rodziny. Jeśli chodzi o kwestię drugą, dotyczy ona raczej samego środowiska specjalistów, którzy z chęci pomocy albo pod presją rodzin oczekujących większego wsparcia instytucjonalnego, skłonni są do wydawania nierzetelnych diagnoz.

Trudno o etyczną ocenę tych zachowań skoro sam system dzieli uczniów z niepełnosprawnością na wymagających większego albo mniejszego wsparcia, wyrażający się np. w liczebności klas. Być może rozwiązaniem byłoby wprowadzenie diagnozy opartej o wytyczne ICF, co analizują S. Sadowska i Z. Janiszewska-Nieścioruk [2018] w nawiązaniu do informacji Ministerstwa Edukacji Narodowej (Reforma edukacji a uczeń ze specjalnymi potrzebami edukacyjnymi). Autorki podchodzą do tego rozwiązania z dużą ostrożnością wskazując na problemy wynikające z odgórnej wykładni diagnozy w duchu funkcjonalnym, odmiennych perspektyw: osoby niepełnosprawnej i osób zaangażowanych w proces rehabilitacji, edukacji, pomocy, terapii itp.; wiedzy i umiejętności osób diagnozujących. Jakkolwiek by nie patrzeć, już sam fakt postawienia diagnozy znajduje swoje odbicie w losach edukacyjnych i ni tylko konkretnych ludzi. W przypadku osoby, która wzbudziła zainteresowanie autorki artykułu, trzeba dodać, że najbardziej specjalistyczną i dostosowaną do potrzeb pomoc otrzymała w szkole specjalnej, zarówno w zakresie kształtowania umiejętności potrzebnych do życia, wiedzy o świecie, jak też rozwoju zainteresowań. 


\section{Sytuacja obecna}

W czerwcu 2017 r. A. ukończyła możliwie wydłużony cykl edukacji szkolnej. Jak wynika z aktualnego orzeczenia wymaga korzystania z systemu środowiskowego wsparcia w samodzielnej egzystencji. W mieście, którym mieszka oferta placówek wsparcia ogranicza się do warsztatów terapii zajęciowej i środowiskowego domu samopomocy. Biorąc pod uwagę deficyty i trudności dziewczyny, potrzebę systematycznych oddziaływań w szerokim zakresie, najbardziej właściwą formą dalszej rehabilitacji wydaje się środowiskowy dom samopomocy. Wsparciem otaczane są tu osoby chorujące psychicznie, niepełnosprawne intelektualnie oraz wykazujące inne zaburzenia czynności psychicznej (w tym autyzm). Jeszcze $\mathrm{w}$ trakcie edukacji w szkole rodzice podjęli decyzję, aby wnioskować o uczestnictwo córki w zajęciach placówki. W tym celu mama A. odbyła wstępną rozmowę z dyrektorem Środowiskowego Domu Samopomocy. Spotkała się z przychylną deklaracją o przyjęciu córki po zakończeniu edukacji. Zdaniem dyrektor placówki, oferta rehabilitacyjna, jaką dysponuje ośrodek pozwoli na dalszy rozwój zainteresowań dziewczyny, jej talentu muzycznego poprzez udział w zajęciach muzycznych czy w klubie zainteresowań. Predyspozycje plastyczne i sprawność manualną rozwijać będzie w ramach terapii zajęciowej i arteterapii. Aby przeciwdziałać regresom i utrzymać prawidłowy poziom funkcjonowania intelektualnego będzie mogła uczestniczyć w zajęciach aktywizacji intelektualnej, biblioterapii z pedagogiem. A przede wszystkim będzie mogła pracować nad deficytami, czyli nabywać i utrwalać umiejętności z zakresu zaradności życiowej w ramach treningów: kulinarnego, praktycznego i porządkowego, dbałości o wygląd zewnętrzny i higieny osobistej. Ponadto będzie miała możliwość korzystania z rehabilitacji ruchowej z fizjoterapeutą oraz grupowej i indywidualnej pomocy psychologicznej. Pomocą i wsparciem może być objęta cała rodzina A. poprzez udział w grupach wsparcia dla rodzin.

Po rozmowie z mamą, można wnioskować, że A. nie przeżywała zbliżającego się zakończenia szkoły. Być może relacje szkolne były dla niej powierzchowne, zapewne poziom deficytów nie pozwalał jej w pełni uświadomić sobie zakończenia pewnego etapu w życiu. Obecnie uczestniczy w zajęciach Środowiskowego Domu Samopomocy ${ }^{3}$, nadal chętnie tworzy prace w różnych technikach plastycznych i wykonuje je bardzo pieczołowicie. Swoje rysowane postacie, przypominające zawsze ulubionego wokalistę Michaela Jacksona są opatrzone duża ilością napisów. Na odwrocie również umieszcza rozległe opisy wymyślonej postaci

3 Jest to placówka typu ABC a to oznacza, że skupia osoby przewlekle chore psychicznie (A), upośledzone umysłowo (B), wykazujące inne przewlekłe zaburzenia czynności psychicznych z wyłączeniem osób czynnie uzależnionych od środków psychoaktywnych (C). 
pani psycholog, bogate w nieskończoną ilość powtarzających się przymiotników. Prace te są z jednej strony bardzo kolorowe, mają wielobarwne tła, postacie są zawsze uśmiechnięte, pojawiają się oznaki waloryzacji: serduszka, kolczyki, wisior$\mathrm{ki}$, ozdoby. Z drugiej jednak strony niepokój wzbudzają czarne ostre palce rąk, hipnotyzujące spojrzenie oczu, wyszczerzone zęby. W ograniczonym zakresie A. rozwija swoje muzyczne pasje.

\section{Perspektywa na przyszłość i wnioski}

Wybór śds wydaje się w tym momencie, w miejscowości, w której mieszka A. optymalnym rozwiązaniem. Realizowane w placówce treningi, zwłaszcza te dotyczące codziennych czynności mogą pomóc rozwinąć umiejętności potrzebne do życia. Pracownie, zwłaszcza o charakterze artystycznym stwarzają możliwości rozwoju zainteresowań. Szczególnie ważny, w sytuacji A. oraz jej rodziny jest kontakt z pedagogiem, psychologiem oraz współpraca ośrodka ze środowiskiem psychiatrów. Placówkę wspiera zaprzyjaźnione Stowarzyszenie, którego członkami są bliscy uczestników ŚDS, pracownicy, znajomi. Dzięki niemu realizowane są projekty skierowane do uczestników. Jeden z ostatnich dotyczył zakładania spółdzielni socjalnych, co zainspirowało parę osób do próby działań prowadzących do aktywizacji zawodowej.

Jeśli jednak powrócimy do biografii A., jej sytuacja życiowa nie wydaje się tak optymistyczna, m.in. z braku alternatywy w wyborze dalszej życiowej drogi (schemat 2).

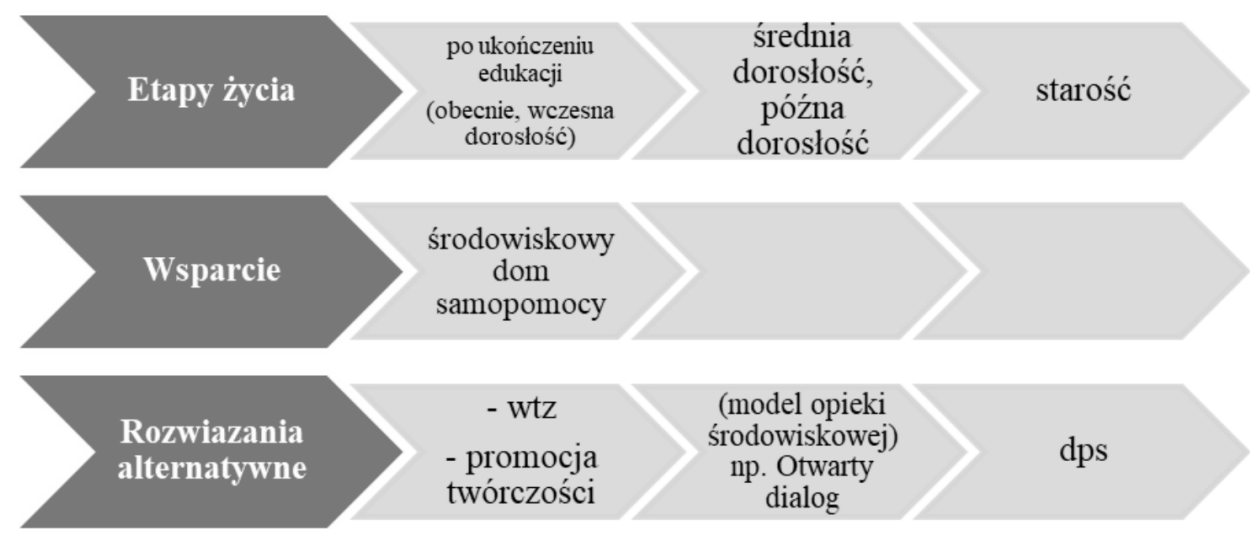

Schemat 2. Alternaatyw w wyborze dalszej życiowej drogi

Źródło: Opracowanie własne. 
Dwudziestopięcioletni człowiek bez obciążenia niepełnosprawnością stoi u progu życia, przed nim zadania związane z pracą, rodziną, dziećmi, godpodarstwem itd. Jaka będzie dorosłość A.? Odwołując się do tytułu jednego z rozdziałów w książce A. Krause [2010] można odpowiedzieć: będzie upośledzona. Mimo blisko dekady od wskazania tego zaniedbanego wątku, sytuacja dorosłych osób z niepełnosprawnością, jak też młodych wkraczających w dorosłość, mieszkańców niewielkich miejscowości pozostaje niezmieniona. Alternatywą dla śds mogą być jedynie warsztaty terapii zajęciowej ewentualnie domy pomocy społecznej. A., której biografia posłużyła jako przykład, nie ma perspektywy życia w mieszkaniu socjalnym, podjęcia pracy, a jej kontakty interpersonalne określać będą uczestnicy śds, wśród nich jej matka, co tylko dowodzi instytucjonalnemu ujednoliceniu dorosłości [Krause 2010: 119].

Wśród przyczyn takiego stanu rzeczy widziałabym, poza brakiem rozwiązań systemowych, różnicujących placówki dla dorosłych osób z niepełnosprawnością, niewielkie zaangażowanie społeczne w działania i chęć zmiany, zarówno wśród pracowników instytucji pomocowych, jak i osób tworzących Stowarzyszenie. Oba środowiska potrzebują odważnych osób, chętnych do rzeczywistych działań w zakresie mieszkalnictwa, zatrudnienia, wdrażania opieki środowiskowej. W przeciwieństwie do istniejących, mają charakter inkluzyjny. Tymczasem otrzymanie zatrudnienia przez pedagoga specjalnego, w zakresie andragogiki specjalnej jest w mieście A. prawie niemożliwe z powodu bezrobocia wśród pedagogów i małego zapotrzebowania w placówkach, m.in. dlatego wielu absolwentów kierunków pedagogicznych pozostaje w dużych aglomeracjach, w których nie tylko łatwiej znaleźć pracę ale i proces zmian przebiega szybciej. To pokazuje, jak ważne są przedsięwzięcia skierowane na zmiany w mentalności i postawach mieszkańców małych społeczności.

Innym problemem jest brak otwartości środowiska medycznego na współpracę ze specjalistami innych dziedzin, zwłaszcza pedagogami specjalnymi. Diagnoza medyczna pozostaje determinującą inne diagnozy, niemniej jednak w przypadku zaburzeń neurorozwojowych albo neurodegeneracyjnych wiele informacji, niemających charakteru medycznego np. dotyczących zachowań, może taką diagnozę uzupełniać. Współpraca jest istotna dla rozwoju środowiskowej opieki, która stwarza możliwość dłuższego życia osób z niepełnosprawnością w środowisku domowym, a korzystania z placówek całodobowych tylko w sytuacjach koniecznych [por. Trojańska 2018]. Zespoły opieki środowiskowej powinny jednak tworzyć osoby otwarte na różne rozwiązania, mające na względzie dobro klientów.

Trzeci problem dotyczy badań jakościowych nad niepełnosprawnością, które poza funkcją naukową, pełnią funkcję społeczną. Przybliżają świat osób z niepełnosprawnością, i mimo ograniczonych możliwości zmiany postaw społecznych, jednak „oswajają" z tym, co wydaje się „inne” i „obce”. W tym zakresie war- 
to przyjrzeć się pokoleniu osób urodzonych, tak jak A., w okresie transformacji ustrojowej, w pierwszej połowie lat 90. Wstępna znajomość biografii sugerowałaby nazwanie tej grupy „pokoleniem spóźnionych szans”. Ich biografie można usytuować już w czasach wielu zmian w praktyce pedagogiki specjalnej np. wczesnego wspomagania, edukacji integracyjnej, działań organizacji pozarządowych dla niepełnosprawnych, a jednak niewielu spośród z nich z tych udogodnień mogło skorzystać. Wprowadzanie zmian wymaga bowiem czasu, a życie toczy się dalej, co w konsekwencji powodowało, że część z nich stawała się „za stara" na korzystanie z nowych rozwiązań instytucjonalnych i doświadczania nowych podejść.

Podsumowując, otwartość, refleksyjność i rzeczywiste działania pozostają jednymi z ważnych czynników warunkujących realizację wsparcia osób z niepełnosprawnością i ich rodzin przez otoczenie społeczne.

\section{Bibliografia}

Axer A. (1983), Społeczne systemy oparcia w środowisku chorego psychicznie, „Studia Socjologiczne", nr 4(91).

Bednarz-Łuczewska P., Łuczewski M. (2012), Podejście biograficzne [w:] Badania jakościowei, t. 2, D. Jemielniak (red.), Wydawnictwo Naukowe PWN, Warszawa.

Kawula S. (1997), Spirala życzliwości: od wsparcia do samorozwoju [w:] Wsparcie społeczne w różnych układach ludzkiego życia, E. Kantorowicz (red.), Wydawnictwo Glob.

Kowalik S. (2007), Psychologia rehabilitacji, Wydawnictwo Akademickie i Profesjonalne, Warszawa.

Krause A. (2010), Wspótczesne paradygmaty pedagogiki specjalnej, Oficyna Wydawnicza „Impuls", Kraków.

Międzynarodowa Klasyfikacja Funkcjonowania, Niepetnosprawności i Zdrowia, WHO 2009.

Palak Z. (2004), Biopsychospołeczna koncepcja niepetnosprawności a wieloaspektowość wsparcia [w:] Wsparcie społeczne w rehabilitacji i resocjalizacji, Z. Palak, Z. Bartkowicz (red.), Wydawnictwo UMCS, Lublin.

Reforma edukacji a uczeń ze specjalnymi potrzebami edukacyjnymi, https://men.gov.pl/ministerstwo/informacje/reforma-edukacji-a-uczen-ze-specjalnymi-potrzebami-edukacyjnymi. html [dostęp: 12.06.2018].

Sadowska S., Janiszewska-Nieścioruk Z. (2018), O diagnozie z wykorzystaniem ICF jako podstawie organizowania pomocy osobom z niepetnosprawnościa - między polityka, wiedza naukowa a praktyka, „Niepełnosprawność Dyskursy Pedagogiki Specjalnej”, nr 29.

Sęk H., Cieślak R. (2004), Wsparcie społeczne - sposoby definiowania, rodzaje i źródła wsparcia, wybrane koncepcje teoretyczne [w:] Wsparcie społeczne, stres $i$ zdrowie, H. Sęk, R. Cieślak (red.), Wydawnictwo Naukowe PWN, Warszawa.

Trojańska M. (2018), "Otwarty dialog" - środowiskowy model wsparcia osób w kryzysach psychicznych i ich rodzin, „Niepełnosprawność. Dyskursy Pedagogiki Specjalnej”, nr 30. 
Twardowski A., (2016), Rola upetnomocnienia rodziców w procesie wczesnego wspomagania rozwoju dzieci z niepełnosprawnościami, „Niepełnosprawność. Dyskursy Pedagogiki Specjalnej", nr 24 .

Wapiennik E., Piotrowicz R. (2002), Niepetnosprawny - petnosprawny obywatel Europy, UKIE, Warszawa.

Wojciechowski F., Opozda-Suder S. (2013), Społeczne konsekwencje i praktyczne aplikacje paradygmatu niepetnosprawności. Perspektywa pedagogiki specjalnej [w:] Miejsce Innego we wspótczesnych naukach o wychowaniu, I. Chrzanowska, B. Jachimczak, K. Pawelczak (red.), Wydawnictwo Naukowe UAM, Poznań.

Yin R. (2015), Studium przypadku w badaniach naukowych, Wydawnictwo UJ, Kraków. 